\title{
Dakwah Islam Moderat dan Realitas Politik Identitas dalam Masyarakat Meme
}

\section{Da'wah of Moderate Islam and the Reality of Political Identity in Society of Memes}

\author{
Abdul Muid Nawawi \\ Universitas Islam Negeri Syarif Hidayatullah Jakarta DPK Prodi Magister IImu \\ Al-Quran dan Tafsir Program Pascasarjana Institut PTIQ Jakarta \\ email: balesaloe@gmail.com \\ Artikel diterima 08 Agustus 2019, diseleksi 19 Oktober 2019, \\ dan disetujui 10 Desember 2019
}

Abstrak: Makalah ini bertujuan untuk menganalisis problem realitas politik identitas di Indonesia dan hubungannya dengan meme-meme serta menawarkan solusi dari dakwah Islam moderat bagi problem tersebut. Jenis kajian ini adalah kualitatif dengan pendekatan studi kasus Pemilihan Presiden dan Pemilihan Legislatif 2019 Indonesia. Data diperoleh dari penelusuran kepustakaan. Hasil kajian menunjukkan bahwa politik identitas adalah alat yang efektif untuk memainkan emosi masyarakat meme demi meraup suara dalam Pemilihan Umum dan sebaliknya, meme-meme adalah alat yang efektif untuk membangkitkan politik identitas. Semua upaya itu dilakukan demi meraih kekuasaan. Posisi dakwah Islam moderat menjadi sangat penting dalam hal ini untuk menjadi solusi bagi perpecahan yang terjadi di dalam masyarakat karena dakwah Islam moderat lebih menekankan pada kepentingan universal daripada kepentingan identitas tertentu.

Kata Kunci: da'wah, Islam moderat, politik identitas, meme

Abstract: This paper aims to analyze the problem of the reality of identity politics in Indonesia and its relationship with memes and offers a solution of moderate Islamic da'wah to the problem. This type of study is qualitative with the case 
study approach of the 2019 Indonesian Presidential Election and Legislative Election. Data obtained from library research. The results of the study show that identity politics is an effective tool to play the emotions of meme society in order to win votes in elections and vice versa, memes are effective tools to generate identity politics. All efforts were made in order to gain power. The position of moderate Islamic da'wah becomes very important in this case to be a solution to the divisions that occur in society because moderate Islamic da'wah emphasizes more on the universal interests rather than the interests of certain identities.

Keywords: da'wah, moderate Islam, identity politics, memes

\section{A. Pendahuluan}

Pemilihan Presidan dan Pemilihan Legislatif 2019 Indonesia sudah lewat dan meninggalkan jejak-jejak yang diduga akan terus membekas hingga paling tidak Pilpres dan Pilleg 2024. Dalam banyak hal, jejakjejak yang ditinggalkan itu adalah jejak-jejak yang kurang baik bagi masa depan demokrasi Indonesia karena dominasi nuansa emosional yang tidak diimbangi rasionalitas yang membayangi para pemilih dan tim sukses para calon. Dampaknya adalah kebenaran tidak lagi penting karena kalah oleh pembenaran hingga membenarkan istilah post truth yang menggambarkan betapa kebenaran tidak lagi penting.

Ada kesan kuat bahwa fenomena ini adalah fenomena yang sedang mengglobal karena banyak negara lain mengalami hal yang serupa dengan dimensi berbeda-beda. Namun terlepas itu sebagai fenomena global, perlu ada perhatian terhadap dampak buruk yang mungkin saja terjadi jika keadaan ini terus berlanjut tanpa ada upaya dari banyak pihak untuk menanggulanginya. Keragaman Indonesia dari segi etnis dan keyakinan adalah modal yang sangat baik bagi pertumbuhan seperti ini. Keragaman etnis dan keyakinan adalah kenyataan yang tidak bisa ditolak. Hanya saja yang harus dilakukan adalah bagaimana keragaman tersebut justru menjadi modal bagi persatuan, bukan modal bagi perpecahan. Di sinilah tawaran dakwah Islam moderat perlu dikedepankan. 
Francis Fukuyama, mengutip William Gibson, Neal Stephenson, dan Bruce Sterling, mengatakan bahwa masa depan tidak dikuasai oleh kepemimpinan diktator yang tersentralisasi, tetapi oleh fragmentasi sosial yang tidak terkontrol yang difasilitasi oleh internet. ${ }^{1}$ Fenomena masyarakat terkoneksi seperti saat ini memang menyimpan banyak paradoks. Di antaranya, sebagai masyarakat terkoneksi, sesungguhnya hampir tidak ada lagi penghalang informasi antara satu individu dengan individu lain dan juga antara satu masyarakat dengan masyarakat lain. Limpahan informasi yang terjadi setiap saat hampir-hampir tidak menyisakan lagi rahasia dan ketidaktahuan tentang suatu masyarakat oleh masyarakat lainnya sehingga sesungguhnya semua masyarakat sudah sangat saling mengenal.

Lalu mengapa di tengah keadaan saling mengenal itu politik identitas malah semakin mengental? Mengapa jurang pemisah antara satu identitas dengan identitas lainnya malah semakin menganga? Apakah sudah tidak berlaku lagi adagium yang mengatakan bahwa tak kenal maka tak sayang? Apakah kondisi saling mengenal yang terjadi sekarang ini tidak cukup untuk saling sayang?

Makalah ini menduga bahwa adagium tak kenal maka tak sayang masih berlaku karena bagaimanapun saling mengenal tetap menjadi kunci untuk mencairkan identitas yang beku. Memahami bahwa kita tidak hanya memiliki satu identitas tetapi memiliki identitas yang beragam di saat bersamaan adalah salah satu bentuk upaya saling mengenal tersebut. Lalu, karena terjadi pengentalan politik identitas, maka kemungkinan yang terjadi adalah ada distorsi informasi yang sengaja dihembuskan oleh pihak-pihak berkepentingan agar membuat masyarakat yang sesungguhnya sudah saling mengenal kembali menjadi tidak saling mengenal hingga memudahkan penyemaian politik identitas. Dan meme-meme yang berseliweran adalah salah satu bentuk kesengajaan tersebut. Karena itulah makalah ini membahas bagaimana memahami realitas politik identitas dalam masyarakat meme dan bagaimana solusi dakwah Islam moderat untuk menanggulangi masalah ini. 


\section{B. Masyarakat Meme}

Kata 'meme' berasal dari bahasa Yunani kata 'mimema' yang berarti 'sesuatu yang ditiru'. ${ }^{2}$ Tujuan meme dibuat sesungguhnya sederhana: menjadi konten yang populer, aktual, dan humoris hingga dengan mudah mendapatkan perhatian di media sosial ${ }^{3}$ namun juga mudah menyebar. ${ }^{4}$ Media sosial adalah kata kunci yang penting dalam hal ini karena media sosial mendefinisikan ulang cara kita berkomunikasi dan berinteraksi dengan produk, merek, masyarakat, serta isu politik. Dan bukan hanya cara berkomunikasi yang berubah, tetapi juga cara mengakses informasi karena data 2017 oleh Reuters Institute Digital News menggambarkan bahwa media sosial dijadikan sumber untuk mengakses informasi oleh para pengguna smartphone. ${ }^{5}$

Seorang librarian bernama Andy Woodworth menyebut meme adalah sebentuk seni karena sebagaimana seni, meme adalah juga gambar yang menyampaikan perasaan atau pesan pemikiran atau kedua-duanya sekaligus yang dampaknya bisa sangat lama dan mendalam. Karena itu, sebagai media visual, meme memenuhi syarat untuk dianggap sebagai karya seni. Meme tidak sesederhana sebuah humor karena meme bisa juga dipakai untuk mengungkapkan hal-hal yang serius seperti politik, agama, dan keadilan sosial. Bahkan meme bisa digunakan sebagai strategi para politisi dan tim suksesnya di media sosial untuk memprovokasi konstituen agar berubah menjadi kelompok yang hiperpartisan. Masa kini adalah masa di mana manusia terus-menerus terhubung satu sama lain dengan sangat intensif dan meme adalah bagian tak terpisahkan dari masa seperti itu. ${ }^{6}$

Meme mempunyai daya adaptasi yang kuat, daya penerimaan yang tinggi dan hidup di dalam platform media sosial yang menjadi ibarat air baginya jika meme diumpamakan sebagai ikan. Siapapun yang terlibat di dalam kehidupan online, pasti akan terpapar meme. ${ }^{7}$ Sebuah meme bisa menyampaikan lebih banyak pesan dan emosi daripada yang mampu disampaikan oleh sebuah teks esai dan itupun ditambah dengan 
mudahnya membuat meme yang jauh lebih mudah dibanding membuat sebuah esai. $^{8}$

Sebagai gambar, meme adalah semesta bahasa tersendiri. Sebuah gambar mempunyai bentuk, gerak-gerik, warna, lighting, dan sebagainya. Menurut Roland Barthes, berbagai macam satuan yang masih harus kita hubungkan ini tidak lain adalah tanda-tanda dalam foto atau "a series of discontinuous signs" yang merupakan syarat mutlak bagi bahasa. Seumpama ada gambar "kepalan tangan", maka itu adalah tanda dalam sistem bahasa yang bisa berarti "siap berkonfrontasi." Demikianlah selanjutnya "kode" dan "tanda" itu saling berhubungan dan membentuk semesta bahasa yang digunakan dan menjadi pengetahuan kita. ${ }^{9}$

Meme bekerja pada aspek mendasar manusia. Manusia adalah makhluk visual dengan tubuh materialnya. Karenanya, komunikasi lewat gambar visual adalah sesuatu yang alami bagi manusia sehingga ekspresi-ekspresi visual hampir ada di mana-mana dalam kehidupan, seperti kartun, iklan, komik, dan instruksi-instruksi manual. Di sinilah media sosial berperan penting karena media sosial adalah wahana yang memudahkan meme-meme terdistribusi dengan cepat dan berlimpah. ${ }^{10}$

Satu lagi yang penting tentang meme adalah bahwa meme seumpama ide-ide yang hidup karena mengalami proses variasi, kompetisi, seleksi, dan pemeliharaan. ${ }^{11}$ Sebuah isu politik, misalnya, bisa lahir dalam banyak variasi meme. Lalu setiap variasi berkompetisi untuk menjadi yang terpopuler (terviral). Karena itu, secara alami, meme-meme tersebut mengalami seleksi, semacam seleksi alam mana di antara yang terkuat dan akan terus bertahan dan menyebar. Dan terakhir, meme-meme tersebut mengendap dalam ingatan dan terpelihara di sana hingga jangka waktu yang lama. Lalu bisa memengaruhi tingkah laku dan tindakan.

\section{Meme dan Politik Identitas}

Kebangkitan politik identitas sangat terbantu oleh media sosial, khususnya meme. Inilah yang menjelaskan mengapa masyarakat yang 
sudah terinformasi dengan baik justru mengalami peristiwa saling tidak mengenal satu sama lain hingga dipermainkan oleh politik identitas. Media sosial dan meme adalah jawaban yang menarik.

Dunia politik sesungguhnya adalah wilayah yang cukup berat untuk dikunyah oleh masyarakat umum yang bukan ahli dalam bidang tertentu. Perdebatan politik yang menyangkut urusan ekonomi tentu mudah dipahami oleh mereka yang menggeluti urusan ekonomi, tetapi tidak mudah bagi mereka yang tidak menggelutinya. Perdebatan politik yang menyangkut urusan budaya juga demikian. Sama dengan perdebatan politik yang menyangkut urusan-urusan lain. Namun berkat internet, media sosial, dan meme, semua itu menjadi konsumsi masyarakat umum dan bukan pakar.

Meme-meme yang beredar "memudahkan" masyarakat umum untuk mencerna informasi yang sesungguhnya tidak mudah untuk dicerna, misalnya kebijakan ekonomi pemerintah. Dampaknya adalah semua orang bisa mengkritisi dan atau mendukung kebijakan ekonomi pemerintah dengan sederet argumen yang besar kemungkinan orangorang itu tidak cukup memahami persoalan kebijakan dan problem ekonomi yang sesungguhnya. Lewat meme yang memang mengandung kekuatan untuk melibatkan emosi khalayak, para khalayak lalu terbelah untuk mengkritisi dan atau mendukung. Kedua kelompok khalayak tersebut menyebarkan pemahaman mereka, bisa lewat meme baru dan bisa pula lewat meme yang mereka dapatkan dari khalayak yang lain. Demikianlah seterusnya hingga meme membentuk polarisasi dalam masyarakat. Politik pun menjadi kunyahan yang mudah dan menjadi budaya populer dan bisa dibicarakan oleh siapa saja atas nama kebebasan berekspresi.

Tergambar pada fenomena di atas bahwa keterlibatan khalayak sesungguhnya adalah keterlibatan artifisial dan di permukaan semata, tidak sampai keterlibatan yang menyentuh dasar persoalan. Betapa tidak, hubungan antara khalayak dengan kenyataan sesungguhnya terhalang oleh meme-meme yang bisa saja dibuat oleh segelintir orang 
yang berkepentingan kepada ambisi-ambisi politik tertentu. Akibatnya, khalayak sesungguhnya memperebutkan dan memperdebatkan hal-hal yang remeh-temeh lalu mereka sebarkan kembali perdebatan tersebut ke internet dan media sosial dalam bentuk meme (atau tidak dalam bentuk meme) hingga menjadi bola salju pemahaman semu yang semakin lama semakin membesar.

Jauhnya sentuhan terhadap persoalan mendasar setiap isu sepertinya memang disengaja oleh mereka yang terlibat di dalam upaya mengomunikasikan pandangan politiknya, terutama jika komunikasi tersebut berlangsung di dunia internet dan media sosial. Dan memememe adalah perwujudan nyata dari kesengajaan untuk menjauhi persoalan mendasar tersebut. Karenanya, timses dan para pendukung fanatik akan selalu berbicara tentang penampilan dan bukan hakikat. Lalu setiap berita yang awalnya dimaksudkan untuk menyampaikan kebenaran dan fakta, kemudian dipermainkan, ditafsirkan ulang, dibuatkan makna-makna baru yang bisa saja melenceng dari kebenaran awal yang hendak disampaikan oleh sebuah berita. Sekali lagi, semua atas dasar kebebasan berekspresi dan berpendapat.

\section{Realitas Politik Identitas}

Meme-meme internet merupakan lambang politik budaya abad ke-21. Dengan kata lain-mengutip Glick Schiller-Kevin Howley menegaskan bahwa di era yang ditandai oleh konvergensi media, komunikasi jaringan dan proliferasi konten yang dienergisasi, meme adalah bagian tak terpisahkan dari 'proses melalui mana hubungan kekuasaan dinyatakan, diterima, diperebutkan, atau ditumbangkan lewat ide, nilai, simbol, dan praktik sehari-hari'. ${ }^{12}$

Karenanya, di satu sisi, meme-meme adalah kenyataan yang tidak bisa ditolak di semua lini kehidupan, termasuk dan terutama dunia politik. Menolaknya hampir sama dengan menolak demokrasi itu sendiri yang sudah seperti udara yang mesti dihirup. Dan memang sebagaimana karakter internet yang menganut demokrasi ekstrim, maka internet 
membuat pertarungan akan selalu terbuka untuk siapa saja yang hendak menggapai kekuasaan. Internet menetralisir apa yang selama ini ada bahwa mereka yang lebih dahulu terlibat di dunia politik sudah pasti memiliki peluang lebih besar untuk memenangkan kontestasi. Internet menegaskan bahwa siapapun mempunyai peluang yang sama untuk menjadi apapun yang mereka mau. Seorang pendatang baru bisa saja menjadi pemenang karena popularitasnya bisa didongkrak secara instan oleh internet.

Pertemuan antara internet, meme-meme, dan politik identitas adalah pertemuan kebetulan dalam sejarah namun menciptakan sebuah gelombang politik yang meluluhlantakkan pemahaman-pemahaman lama tentang komunikasi politik. Secara khusus politik identitas seperti menemukan momentumnya bersama internet dan meme-meme.

Identitas sesungguhnya adalah keterikatan individu kepada sebuah komunitas. Dalam hal ini, kita memiliki banyak identitas yang tumpang tindih satu sama lain: identitas politik, identitas geografis, identitas etnis, identitas agama, identitas kelompok, identitas kekerabatan, dan seterusnya. Sedangkan istilah identitas politik muncul pada tahun 1970-an dan menyebar di tahun 1980-an sebagai respons terhadap ketidakadilan sosial, diskriminasi atau serangan yang dialami oleh anggota minoritas tertentu. ${ }^{13}$ Ya, paling tidak istilah politik identitas adalah istilah yang mulai disebut-sebut sekitar 30 tahun terakhir sebagai manifestasi kontemporer yang merujuk kepada gerakan sosial pascaperang yang berbeda dengan gerakan politik berbasis partai dan tidak sesederhana pertentangan antara kelas pemilik melawan kelas pekerja sebagaimana ada sebelumnya. ${ }^{14}$

Perjuangan hak-hak sipil orang-orang Afrika-Amerika dipicu oleh politik identitas, demikian pula dengan perjuangan untuk membangun dan memastikan supremasi kulit putih melalui perbudakan dan Jim Crow. Dengan kata lain, politik identitas tidak hanya berada di belakang upaya kelompok-kelompok yang terpinggirkan untuk mencari ganti 
rugi: politik identitas juga mendorong upaya kelompok dominan untuk memarginalkan orang lain. ${ }^{15}$

Indonesia adalah negara dengan keragaman yang luar biasa dan direkatkan oleh dasar negara bernama Pancasila dan UUD 1945 guna memayungi keragaman agama, etnis, dan wilayah. Namun perekat tersebut tidak selalu mampu meredam gejolak yang mengatasnamakan diri agama maupun etnis hingga mengganggu identitas nasional.

Tren global berupa kebangkitan politik identitas adalah kelanjutan dari ketidakpuasan terhadap institusi-institusi negara dan yang utama adalah dalam hal keamanan. ${ }^{16}$ Hubungan antara individu di mana pun belahan bumi ini yang semakin intensif beserta perbatasan antarnegara yang semakin temaram dan rapuh akibat intensitas informasi dan komunikasi serta koneksi antara manusia benar-benar meretakkan ketertiban tradisional yang dulu ada. Dampaknya adalah keamanan yang semakin tidak menentu. Dampak selanjutnya adalah politik identitas yang merebak karena dianggap sebagai satu-satunya perlindungan terakhir dari ancaman luar dan ancaman asing. ${ }^{17}$

Meski dalam banyak hal politik identitas juga tidak kalah rapuhnya, namun ketidakpercayaan kepada ideologi-ideologi lama tergantikan oleh politik identitas yang memang mempunyai kelebihan dalam hal kekuatan untuk memobilisasi publik. Radikalisasi muncul dalam konteks seperti ini, konteks politik identitas yang semakin sempit serta respons terhadap mereka yang juga tidak kalah eksklusifnya, maka yang kemudian hadir hanyalah proses radikalisasi. ${ }^{18}$

Konsep mayoritas-minoritas bisa lahir dari alur kisah seperti di atas - Eli Steele menyebutnya the minority state of mind. Kata "minoritas" sering digunakan secara umum bersamaan dengan kata "mayoritas" untuk merujuk pada jumlah populasi. Tetapi minoritas juga merupakan konstruksi sosial yang digunakan oleh beberapa orang untuk menegakkan loyalitas terhadap politik kelompok ras yang tertindas. Untuk memasuki keadaan pikiran minoritas dipastikan terjadi upaya menceraikan diri 
dari identitas yang lebih besar untuk merangkul identitas yang jauh lebih sempit berdasarkan politik ras. ${ }^{19}$ Biasanya, dengan merangkul pola pikir korban yang jika dikaitkan dengan isu rapuhnya keamanan negara dan kegagalan institusi negara, maka itu berarti korban ketidakamanan dan korban kegagalan negara.

Ketika ada ketidakpercayaan kepada institusi dan ditambah oleh rasa ketidakamanan yang berakibat pada menguatnya gagasan identitas, maka secara alami kesetiaan kepada identitas itu semakin lama semakin menyempit dan meninggalkan identitas politik yang lebih besar dan lebih luas. Tentu saja ini adalah gejala yang alami karena semakin sempit sebuah kelompok identitas, maka perasaan aman akan semakin terasa membesar bagi anggota kelompoknya.

Meski terpecah kepada kelompok-kelompok yang semakin mengecil, namun kelompok politik identitas akan semakin solid dan itu adalah sebuah peluang tersendiri bagi kelompok-kelompok yang hendak memanfaatkan politik identitas untuk kepentingan mereka. Itu bisa terjadi karena meski terpecah, kelompok-kelompok ini sesungguhnya memiliki kepentingan yang sama, yaitu hendak berkuasa dan itu tidak mungkin mereka lakukan sendiri-sendiri karena mereka kecil, baik dari sisi dana maupun sumber daya. Satu-satunya yang bisa mereka lakukan adalah "bersatu" dengan berdasar pada perasaan keterancaman bersama dan perasaan kekecewaan terhadap institusi-institusi publik.

Kristina Kausch menyebutkan bahwa keadaan seperti di atas sangat mungkin terjadi di dalam kekosongan politik dan ideologi dan ditambah oleh kegagalan institusi-institusi publik dalam menjalankan fungsinya untuk melayani masyarakat dan juga lemahnya akuntabilitas institusiinstitusi publik tersebut. ${ }^{20}$ Karena itu, narasi keterancaman negara dari kekuatan asing adalah isu yang terus-menerus didengungkan oleh para pengusung politik identitas. Bersamaan dengan itu, mereka juga memainkan isu-isu kegagalan negara dan institusi-insititusi negara untuk menjalankan fungsinya dengan baik demi kesejahteraan masyarakat. 
Dengan demikian, politik identitas mempunyai sebab-sebab awal kemunculannya sendiri, seperti keterancaman negara dari kekuatan asing akibat melemahnya sistem keamanan di dunia yang semakin terkoneksi seperti saat ini serta kegagalan institusi-institusi negara. Karenanya, para penganjur politik identitas sangat fasih berbicara tentang kedua isu tersebut.

Mengutip Fukuyama, John Sides, Michael Tesler, dan Lynn Vavreck menyebutkan bahwa politik identitas menjadi berlebihan ketika masingmasing identitas menegaskan keterpisahan identitasnya lalu menuntut rasa hormat yang lain kepada mereka, terutama dari pihak yang dicap sebagai arus utama. ${ }^{21}$ Dalam hal ini, politik identitas lebih memfokuskan diri pada nilai-nilai individual atau kelompok tertentu daripada nilainilai bersama sebagai warga sebuah negara, dan apa yang mengikat mereka sebagai anggota komunitas nasional. ${ }^{22}$

Lalu mengapa demokrasi liberal bisa sampai pada persoalan pelik politik identitas? Bisa jadi karena demokrasi liberal lah yang memberi ruang bagi politik identitas. Kebebasan penuh untuk bereskpresi dan berpendapat adalah bagian tidak terpisahkan dari demokrasi liberal dan itu termasuk kebebasan menunjukkan identitas. Bisa jadi pula karena demokrasi liberal hanya memberi ruang bagi kapitalisme pasar bebas dan tidak memberi ruang alternatif ekonomi selain itu. Kapitalisme pasar bebas memberi ruang bagi ide-ide yang dilemparkan ke pasar bebas untuk diterima atau ditolak. ${ }^{23}$

Sebagai nuansa baru dalam dinamika demokrasi, politik identitas adalah hal yang seharusnya wajar karena demokrasi memang adalah sistem yang memungkinkan dan membuka dirinya untuk dikoreksi. Itulah kelebihan sekaligus kekurangan demokrasi. Politik identitas adalah bentuk baru kritik terhadap demokrasi. Ketidakwajaran mulai terjadi ketika masing-masing kekuatan identitas berebut pengaruh atas nama identitasnya. Kisah politik identitas adalah kisah yang berawal dari upaya atas nama demokrasi untuk memberi ruang bagi suara-suara 
kecil, minoritas, dan terpinggirkan untuk menceritakan siapa mereka sesungguhnya lewat sudut pandang mereka sendiri. Kini, sebagai dampak dari demografi dan pola komunikasi yang berubah secara radikal, politik identitas berubah menjadi medan perang identitas untuk memperebutkan dominasi. Kisah politik identitas yang awalnya adalah merangkul, kini berubah menjadi mengeliminasi. Semua atas nama demokrasi.

Dominasi yang diperjuangkan oleh politik identitas adalah perjuangan yang rasis, sebagaimana disebutkan oleh Peter Baldwin. Bukti rasisme yang berkerja di dalam politik identitas adalah perbedaannya yang mendasar dengan perjuangan yang mirip dengannya di akhir abad lalu yang disebutkan oleh Martin Luther King dalam pidatonya pada tahun 1963 yang memimpikan suatu hari ketika anak-anaknya dinilai bukan karena warna kulitnya tetapi karena the content of their character. Dan bukankah perjuangan politik identitas kini malah meneriakkan hal sebaliknya ${ }^{24}$

Namun Fukuyama curiga, jangan-jangan ramainya politik identitas bukanlah perayaan atas keragaman identitas. Karena itu, politik identitas bukan pula perlawanan kaum terpinggirkan agar suara mereka didengarkan dan aspirasi mereka diberi ruang. Tetapi yang terjadi sesungguhnya adalah identitas-identitas tersebut diciptakan oleh kekuatan yang lebih besar dan berkepentingan terhadap kekuasaan yang memahami bahwa politik identitas adalah cara paling efektif untuk melakukan pemberontakan (dan juga pergantian kekuasaan). ${ }^{25}$ Untuk itu, sang pemilik kekuatan harus membiayai upayanya menciptakan identitas-identitas tersebut. Jika dominasi berhasil digapai, maka ada kemungkinan sang pemilik kekuatan dan identitas-identitas politik ciptaannya akan terus menjalin hubungan baik. Namun jika dominasi gagal digapai, maka hampir bisa dipastikan bahwa hubungan keduanya akan pecah, namun masih bisa kembali bersama jika kembali ada kepentingan yang menyatukan. 
Namun, cara pandang berbeda tentang politik identitas yang tidak semuram dan securiga Fukuyama disampaikan oleh Suzanna Danuta Walters yang mengungkapkan bahwa mengapa perjuangan ras kulit hitam di masa lalu tidak disebut politik identitas dan kini disebut politik identitas dengan nada memandang sebelah mata? Bukankah setiap perjuangan politik adalah perjuangan kepentingan identitas di saat bersamaan? ${ }^{26}$ Sesungguhnya yang dilakukan Walters adalah upaya untuk tidak secara gegabah memukul rata setiap upaya perjuangan sekelompok orang adalah semata-mata gerakan politik identitas karena bisa jadi pukul rata sedemikian adalah upaya pemberangusan hak-hak yang sebenarnya memang ada.

Pandangan yang serupa dengan Walters diungkapkan oleh Eric Ward. Menurut Ward, tidak boleh serta-merta menyalahkan komunitaskomunitas identitas tertentu dalam hal upaya mereka yang sedang memperkuat posisi identitasnya. Itu bukanlah sesuatu yang salah. Yang menjadi salah adalah apabila komunitas-komunitas tersebut memperlakukan politik identitas sebagai tujuan akhir. Hal ini terutama sering dilakukan oleh para pemimpin mereka. Padahal sesungguhnya identitas politik adalah jembatan dalam upaya menegakkan keadilan. Perbedaan dipahami untuk mengenali persamaan kemanusiaan. ${ }^{27}$

\section{E. Dakwah Islam Moderat Sebagai Solusi}

Islam itu sendiri adalah identitas jika Islam dilihat sebagai nama dan karena itu, Islam mempunyai potensi untuk bergumul di dalam politik identitas. ${ }^{28}$ Sejarah membuktikan bahwa terjadi dinamika dalam relasi antara Islam sebagai identitas dengan Islam sebagai pesan-pesan kemanusiaan. Di satu sisi, Islam adalah nama dengan ciri-ciri tertentu dalam hukum dan ritualnya. Karena itu, Islam adalah sebuah identitas tersendiri yang berbeda dengan identitas-identitas lainnya. Namun di sisi lain, Islam berisikan pesan-pesan yang bersifat universal dengan misi kemanusiannya. Kedua sisi itulah yang mengalami pergumulan untuk memperebutkan dominasi di dalam wacana keislaman. 
Ketika Islam hadir pertama kali di Jazirah Arabia (Makkah), tidak begitu tampak Islam sebagai perjuangan identitas. Saat itu, Islam berbicara tentang isu-isu kemanusiaan seperti perbudakan, kemiskinan yang terstruktur, penindasan terhadap perempuan dan hak-haknya, penindasan terhadap anak yatim, dan sebagainya. Meski demikian, inspirasi perjuangan tersebut bisa melahirkan politik identitas seperti perjuangan kulit berwarna, perjuangan perempuan, perjuangan kelas sosial, dan sebagainya.

Di masa-masa selanjutnya, dimulai di Madinah, Islam sebagai identitas mulai menguat yang ditandai dengan hadirnya wilayah tertentu yang bisa disebut Islam, golongan tertentu yang bisa disebut Islam, sikap tertentu yang bisa disebut Islam, dan seterusnya hingga cara berpakaian tertentu. Namun boleh disebut bahwa perjuangan membela kemanusiaan masih cukup kental terjaga hingga Nabi Muhammad SAW wafat dan bahkan berlanjut hingga empat orang penggantinya. Namun setelah itu, Islam sebagai identitas semakin dominan jika dibandingkan dengan Islam sebagai perjuangan membela kemanusiaan. Hingga pada titik tertentu, Islam sebagai identitas jauh lebih penting daripada kemanusiaan itu sendiri yang merupakan isu paling awal yang diperjuangkan oleh pribadi Nabi Muhammad SAW sendiri.

Perdebatan tentang bagaimana Islam seharusnya diperjuangkan sangat diwarnai oleh sejarah singkat menentukan sejak lahirnya Islam di Makkah hingga usainya khalifah keempat dan oleh sejarah panjangyang juga menentukan-sejak usainya khalifah keempat hingga saat ini. Mereka yang merujuk kepada sejarah singkat mempunyai landasan argumennya sendiri dan mereka yang merujuk kepada sejarah panjang juga memiliki pijakan alasannya sendiri beserta dalil-dalil yang bisa diperdebatkan oleh kedua belah pihak hingga tak berakhir.

Islam di Indonesia pun mewarisi perdebatan serupa dan tidak jauh berbeda. Satu kelompok dengan sangat teguh berpegang kepada model sejarah singkat umat Islam yang dampaknya adalah mereka tidak begitu sering dan bahkan cukup enggan menamai perjuangan mereka dengan 
nama "Islam". Kelompok satu lagi menggigit kuat dengan gigi geraham sejarah panjang umat Islam yang dampaknya adalah mereka begitu menyenangi nama-nama "Islam" untuk perjuangan mereka. Kelompok yang pertama itulah yang sering menganggap kelompok kedua sebagai gerakan politik identitas. Sedangkan kelompok kedua dengan bangga menyebut bahwa justru Islam sebagai identitas adalah sesuatu yang tidak bisa lagi ditawar-tawar.

Kelompok yang pertama sudah cukup lama bertahan tanpa tantangan berarti. Setidaknya sejak Islam datang ke Nusantara hingga sebelum ditemukannya internet dan meme-memenya. Namun sejak internet hadir dengan tantangan borderless-nya, identitas-identitas Islam lain gencar mendatangi Nusantara. Lebih dahulu dari internet adalah tantangan transportasi dan mobilisasi manusia yang sangat tinggi akibat teknologi membuat ancaman terhadap keamanan negara sangat tinggi hingga rasa terancam adalah perasaan yang bisa dipermainkan setiap saat. Ditambah lagi kegagalan demi kegagalan pemerintahan sejak Orde Lama, Orde Baru, hingga Orde Reformasi yang membuat setiap ikhtiar perjuangan Islam-baik yang terinspirasi sejarah singkat umat Islam maupun yang terinspirasi sejarah panjang umat Islam - berlomba tampil untuk memberikan solusi.

Istilah Islam moderat kadang diandaikan dengan Islam yang tidak ekstrem ke kiri dan tidak ekstrem ke kanan. Bisa jadi istilah tersebut diilhami oleh istilah yang berasal dari Al-Qur'an, yaitu ummatan wasathan (umat pertengahan). Hal inilah yang dilakukan oleh Ahmad Najib Burhani ketika membahas moderatisme Islam. Burhani diilhami oleh empat pemahaman umum tentang ummatan wasathan, yaitu: pertama, yang mengartikan ummatan wasathan dengan masyarakat yang mengupayakan keadilan di muka bumi. Kedua, yang mengartikan ummatan wasathan dengan umat yang berada di antara Yahudi dan Kristen, yaitu menjadi penyeimbang antara kedua agama tersebut. Ketiga, yang mengartikan ummatan wasathan dengan umat yang terbaik, dan tentu saja dibandingkan dengan Yahudi dan Kristen. Keempat, yang 
mengartikan ummatan wasathan dengan umat pemimpin, yaitu umat Islam adalah pemimpin dunia. ${ }^{29}$

Keempat pemaknaan ummatan wasathan di atas bisa menjadi tawaran makna dalam hal Islam diperbadingkan dengan agama-agama lain atau umat Islam dengan umat-umat lain. Namun tidak bisa menjadi tawaran makna dalam hal elemen-elemen di dalam Islam itu sendiri yang dibandingkan antara satu dengan yang lain yang melahirkan istilah Islam moderat dan Islam radikal. Karena itulah, jika ummatan wasathan diterapkan ke dalam Islam itu sendiri di dalam dirinya sendiri, maka istilah Islam ekstrem kiri dan Islam ekstrem kanan dan atau Islam radikal dan Islam moderat itu muncul. Persoalannya, kesemuanya bisa sangat bertentanagan satu sama lain tetapi tetap saja penamaan "Islam" diterapkan kepada semuanya atau paling tidak, para penganutnya bersikeras untuk menamakan diri "Islam". Karena itu, diperlukan pemaknaan lain.

Sesungguhnya Islam moderat adalah Islam yang merangkul semuanya, baik kiri maupun kanan. Bahkan Islam moderat juga merangkul yang berada di luar Islam itu sendiri, seperti agama-agama lain. Islam moderat merangkul semuanya dengan cara mengedepankan misi universal kemanusiaan. Dalam konteks keindonesiaan, Islam moderat adalah Islam yang mengakui kehadiran agama-agama lain sebagai bagian dari bangsa Indonesia dan bersama-sama mewujudkan kepentingan bersama dan kemajuan bersama.

Islam moderat adalah upaya menjunjung tinggi perjuangan kemanusiaan sebagaimana tergambar pada sejarah singkat umat Islam sejak di Makkah hingga empat pemimpin pengganti Nabi Muhammad SAW yang disebut Khulafaurrasyidin. Di dalam Al-Qur'an, moderatisme Islam tergambar di dalam ayat-ayat yang turun pada periode Mekah (Makkiyyah) $^{30}$ dengan dua ukuran: pertama: redaksinya yang universal karena memakai kalimat (salah satunya): Yâ ayyuhan nâs (Wahai, manusia!); dan kedua: pesannya yang universal. Untuk contoh yang 
kedua ini salah satunya adalah Surah Al-Mâ'ûn/107:1-7: Tahukah kamu (orang) yang mendustakan agama? Maka itulah orang yang menghardik anak yatim dan tidak mendorong memberi makan orang miskin. Maka celakalah orang yang shalat (yaitu) orang yang lalai terhadap shalatnya, yang berbuat ria, dan enggan (memberikan) bantuan.

Surah Al-Mâ'ûn adalah perlambang betapa identitas tidak lebih penting daripada kemanusiaan. Di dalam surah tersebut disebutkan dua macam identitas, yaitu identitas dîn (agama) dan identitas mushallîn (orang-orang yang shalat). Dîn (agama) sebagai identitas adalah simbol bagi nama sebuah perjuangan dan mushallîn (orang-orang yang shalat) sebagai identitas adalah simbol bagi ritual sebuah perjuangan. Kedua bentuk identitas itu-disebutkan oleh Surah Al-Mâ'ûn-dianggap tidak ada artinya jika pesan-pesan kemanusiaan seperti menolong anak yatim dan orang miskin itu tidak dilaksanakan. Moderatisme Islam ini adalah perjuangan yang melampaui sekat-sekat identitas dan melampaui kepentingan golongan.

Dalam bingkai Islam moderat seperti di atas, dakwah Islam harusnya ditegakkan. Di dalam Al-Qur'an, Surah al-Nahl/16:125, pedoman dakwah secara jelas disebutkan: Serulah (manusia) kepada jalan Tuhan-mu dengan hikmah dan pelajaran yang baik dan bantahlah mereka dengan cara yang baik. Sesungguhnya Tuhanmu Dialah yang lebih mengetahui tentang siapa yang tersesat dari jalan-Nya dan Dialah yang lebih mengetahui orang-orang yang mendapat petunjuk.

Penyebutan Al-Qur'an untuk "jalan Tuhan" di dalam ayat di atas adalah dengan kata sabîl Rabbik. Dalam bahasa Al-Qur'an, Tuhan kadang disebutkan dengan Rabb, Ilâh, atau Allâh. Rabb itu sendiri bermakna dasar pada kata kerja "memelihara". Karena itu, selain bermakna "Tuhan", Rabb juga bermakna "Pemelihara". Karena itu pula, kerangka besar dakwah adalah kerangka pemeliharaan, penjagaan, dan perawatan; tidak berkerangka pengrusakan, pemusnahan, dan pembiaran. Dalam pemaknaan seperti inilah, dakwah berkaitan dengan Islam moderat, yaitu 
bahwa pemeliharaan hanya bisa terlaksana dalam kebersamaan; dan kebersamaan hanya bisa hadir dalam universalitas misi kemanusiaan. Politik identitas bertentangan dengan misi kemanusiaan yang universal karena lebih mementingkan golongan sendiri dibanding kebersamaan. Karenanya, kerangka besar dakwah berupa pemeliharaan bukanlah menjadi tujuan utama politik identitas, tetapi kemenangan golongan.

Pemilihan Presidan dan Pemilihan Legislatif 2014 pernah dianggap sebagai puncak gesekan akibat politik identitas namun sepertinya Pemilihan Presiden dan Pemilihan Legislatif 2019 jauh lebih dahsyat. Masyarakat Indonesia cukup sukses melewati 2014 dan luka-luka yang mereka alami sedikit demi sedikit menyembuh. Namun di 2019, lukaluka itu kembali menganga, dan bahkan lebih dalam dari sebelumnya. Barangkali ada yang cukup optimis bahwa luka-luka itu akan kembali sembuh seperti sediakala karena bukankah Indonesia sudah pernah terluka sebelumnya-bahkan sejak 1945-dan semuanya kembali sembuh? Namun barangkali juga ada yang cukup khawatir bahwa luka 2019 ini berbeda dengan luka-luka sebelumnya. Luka yang satu ini menganga lebih lebar dan mencengkeram lebih dalam. ${ }^{31}$ Kita perlu opotimis bahwa luka itu pasti sembuh, tapi kita juga perlu berbuat agar luka itu benar-benar sembuh.

\section{F. Kesimpulan}

Berdasarkan pembahasan di atas, maka didapatkan kesimpulan:

1. Politik identitas lahir karena berbagai sebab, seperti kegagalan negara dalam hal pemerataan ekonomi, sosial, dan politik; arus informasi yang melimpah lewat internet; serta menipisnya batas antarnegara akibat arus informasi dan migrasi. Kenyataan seperti itu dimanfaatkan oleh pihak yang hendak melanggengkan kekuasaannya dan juga pihak yang hendak merebut kekuasaan dengan cara memainkan emosi masyarakat lewat kebangkitan (membangkitkan) politik identitas. Untuk memudahkan 
tercapainya tujuan tersebut, kedua belah pihak menggunakan meme-meme sebagai alat.

2. Akibat yang terjadi kemudian terjadi adalah terbelahnya masyarakat dalam kotak-kotak identitas yang sangat sulit menyatu akibat dominannya nuansa emosional daripada rasional karena meme-meme yang digunakan memang secara natural dan atau disengaja berfungsi untuk memainkan emosi masyarakat. Itu terjadi karena meme-meme adalah sesuatu yang secara natural menghilangkan konteks sebuah peristiwa.

3. Dakwah Islam moderat adalah solusi yang tepat bagi keterbelahan masyarakat akibat politik identitas yang menjadikan memememe sebagai alatnya. Penekanan dakwah moderat Islam pada hal-hal yang universal dan pengabaiannya terhadap hal-hal yang partikular, sementara, dan hanya untuk kepentingan golongan tertentu adalah potensi yang sangat besar untuk menyatukan kembali masyarakat. 


\section{Daftar Pustaka}

Abrams, Stacey Y., "Identity Politics Strengthens Democracy," dalam Foreign Affairs, Maret/April, 2019

Baldwin, Peter, "The Inherent Racism of Identity Politics," dalam Quadrant, Januari-Februari, 2019

Bebić, Demagoj dan Marija Volarevic, "Do Not Mess With a Meme: The Use of Viral Content in Communicating Politics," dalam Communication \& Society, Vol. 31 (3), 2018.

Behrent, Michael C., "France's Anti-Liberal Left," dalam Dissent, Musim Semi, 2018.

Bouché, Vanesa, "From Categories to Context: Identity Meaning and Political Engangement," dalam Social Science Quarterly, Vol. 99, No. 2, Juni, . 2018.

Burhani, Ahmad Najib, "Al-Tawassuth wa al-I'tidâl: The NU and Moderatism in Indonesian Islam," dalam Asian Journal of Social Science, 40, 2012.

Fukuyama, Francis, "Against Identity Politics: The New Tribalism and the Crisis of Cemocracy," dalam Foreign Affairs, September/Oktober, 2018.

Howley, Kevin, "I Have a Drone: Internet Memes and the Politics of Culture," dalam Interactions: Studies in Communication \& Culture, Vol. 7, No., 2, 2016.

Kausch, Kristina, "Identity Politics and Regional Order in the Levant," dalam International Relations, Vol. 15, Edisi 60, 2018.

Pabst, Adrian, "The Politics of the Void: The Search for the Common Good in the Age of Individualism and Identity Liberalism," dalam New Stateman, 24-30 Agustus, 2018. 
al-Qaththan, Manna', Mabâhits fì 'Ulûm al-Qur'ân, Kairo: Maktabah Wahbah, t. th.

Rutherford, Jonathan, "Toward a New Left Conservatism: Why the Democratic Nation Coming Apart," dalam New Stateman, 28 Juni-4 Juli, 2019.

Scott, Veronica dan Timothy Bill, "Memes: The Interaction Between Imagery and Subculture An Analysis of Situation, Race, and Gender on the Pi Kappa Delta Social Media App," dalam The Forensic of Pi Kappa Delta, Vol. 103, Musim Dingin, 2018.

Sharma, Harshit, "Memes in Digital Culture adn Their Role in Marketing and Communication: A Study in India," dalam Interactions: Studies in Communication \& Culture, Vol. 9, Number 3, 2018.

Sides, John, Michael Tesler, dan Lynn Vavreck, “Identity Politics Can Lead to Progress," dalam Foreign Affairs, Maret/April, 2019.

Steele, Eli, "From White Supremacy to Identity Politics," dalam Commentary, Oktober, 2018.

Sunardi, St., Semiotika Negativa, Yogyakarta: Penerbit Buku Baik, 2004.

Vatikiotis, Michael, "Spreading a Creed of Hate Thy Neighbour," dalam The World Today, Juni \& Juli, 2019.

Walters, Suzanna Danuta, "Currents: Feminist Key Concepts and Controversies in Defense of Identity Politics," dalam Signs: Journal of Women in Culture and Society, Vol. 43, No. 2, 2018.

Ward, Eric, "The Evolution of Identity Politics," dalam Tikkun, Musim Dingin/Musim Semi, 2018.

Woodworth, Andy, "My Body is Ready: Best Practices for Using Memes on Library Social Media," dalam Reference \& User Services Quarterly, Vol. 58, Issue 2, Winter, 2018. 


\section{Endnotes}

1. Francis Fukuyama, "Against Identity Politics: The New Tribalism and the Crisis of Cemocracy," dalam Foreign Affairs, September/Oktober, 2018, h. 113.

2. Harshit Sharma, "Memes in Digital Culture adn Their Role in Marketing and Communication: A Study in India," dalam Interactions: Studies in Communication E Culture, Vol. 9, Number 3, 2018, h. 304. Demagoj Bebić dan Marija Volarevic, "Do Not Mess With a Meme: The Use of Viral Content in Communicating Politics," dalam Communication \& Society, Vol. 31 (3), 2018, h. 45 .

3. Media sosial sekelompok aplikasi berbasis internet yang dibangun di atas fondasi ideologis dan teknologi Web 2.0 dan yang memungkinkan pembuatan dan pertukaran Konten Buatan Pengguna. Veronica Scott dan Timothy Bill, "Memes: The Interaction Between Imagery and Subculture An Analysis of Situation, Race, and Gender on the Pi Kappa Delta Social Media App," dalam The Forensic of Pi Kappa Delta, Vol. 103, Musim Dingin 2018, h. 36.

4. Demagoj Bebić dan Marija Volarevic, "Do Not Mess With a Meme: The Use of Viral Content in Communicating Politics," h. 44.

5. Ada beberapa istilah untuk menggambarkan betapa media sosial begitu merevolusi cara kita berkomunikasi dan cara kita mendapatkan informasi, seperti spreadability (menggabarkan potensi khalayak menyebarkan konten berdasarkan kepentingan dan tujuannya masing-masing), stickiness (menggambarkan aspek media yang mampu menimbulkan keterikatan mendalam pada para khalayak dan bisa memotivasi mereka untuk menyebarkan apa yang merekar rasakan), media virus dan viral journalism (menjelaskan penciptaan konten yang interaktif, saling terhubung, emosional, menarik, dan langsung hingga berdampak viral. Demagoj Bebić dan Marija Volarevic, "Do Not Mess With a Meme: The Use of Viral Content in Communicating Politics," h. 44-45.

6. Andy Woodworth, "My Body is Ready: Best Practices for Using Memes on Library Social Media," dalam Reference \& User Services Quarterly, Vol. 58, Issue 2, Winter 2018, h. 87. 
7. Demagoj Bebić dan Marija Volarevic, "Do Not Mess With a Meme: The Use of Viral Content in Communicating Politics," h. 43.

8. Andy Woodworth, "My Body is Ready: Best Practices for Using Memes on Library Social Media," h. 88.

9. St. Sunardi, Semiotika Negativa, (Yogyakarta: Penerbit Buku Baik, 2004), h. 149.

10. Andy Woodworth, "My Body is Ready: Best Practices for Using Memes on Library Social Media," h. 88.

11. Demagoj Bebić dan Marija Volarevic, "Do Not Mess With a Meme: The Use of Viral Content in Communicating Politics," h. 45.

12. Kevin Howley, "I Have a Drone: Internet Memes and the Politics of Culture," dalam Interactions: Studies in Communication \& Culture, Vol. 7, No., 2, 2016, h. 158.

13. Dikutip dari Elin Diamond oleh Kristina Kausch dalam Kristina Kausch, "Identity Politics and Regional Order in the Levant," dalam International Relations, Vol. 15, Edisi 60, 2018, h. 22.

14. Suzanna Danuta Walters, "Currents: Feminist Key Concepts and Controversies in Defense of Identity Politics," dalam Signs: Journal of Women in Culture and Society, 2018, Vol. 43, No. 2, h. 476.

15. John Sides, Michael Tesler, dan Lynn Vavreck, "Identity Politics Can Lead to Progress," dalam Foreign Affairs, Maret/April, 2019, h. 163.

16. Perasaan tidak aman yang dimaksud adalah perasaan tidak aman dari ancaman kekuatan globalisasi seperti penyakit, arus modal yang kacau, terorisme, perubahan iklim, pergerakan pengungsi, dan imigasi dalam skala besar. Jonathan Rutherford, "Toward a New Left Conservatism: Why the Democratic Nation Coming Apart," dalam New Stateman, 28 Juni-4 Juli, 2019, h. 33.

17. Kristina Kausch, “Identity Politics and Regional Order in the Levant," h. 24.

18. Kristina Kausch, “Identity Politics and Regional Order in the Levant," h. 24.

19. Eli Steele, "From White Supremacy to Identity Politics," dalam Commentary, Oktober 2018, h. 37.

20. Kristina Kausch, “Identity Politics and Regional Order in the Levant," h. 24. 
21. John Sides, Michael Tesler, dan Lynn Vavreck, "Identity Politics Can Lead to Progress," h. 163-164.

22. Adrian Pabst, "The Politics of the Void: The Search for the Common Good in the Age of Individualism and Identity Liberalism," dalam New Stateman, 24-30 Agustus 2018, h. 26.

23. Michael C. Behrent, "France's Anti-Liberal Left," dalam Dissent, Musim Semi, 2018, h. 107.

24. Peter Baldwin, “The Inherent Racism of Identity Politics," dalam Quadrant, Januari-Februari 2019, h. 18.

25. Stacey Y. Abrams, "Identity Politics Strengthens Democracy," dalam Foreign Affairs, Maret/April, 2019, h. 162.

26. Suzanna Danuta Walters, "Currents: Feminist Key Concepts and Controversies in Defense of Identity Politics," h. 476.

27. Eric Ward, "The Evolution of Identity Politics," dalam Tikkun, Musim Dingin/Musim Semi, 2018, h. 24.

28. Berbagai identitas dan identifikasi kelompok yang berbeda memiliki manifestasi politik. Misalnya, literatur politik tentang ras, jenis kelamin, dan agama adalah identitas yang menentukan keberpihakan, ideologi, preferensi kebijakan, perilaku memilih, dan partisipasi politik. Vanesa Bouché, "From Categories to Context: Identity Meaning and Political Engangement," dalam Social Science Quarterly, Vol. 99, No. 2, Juni 2018, h. 711.

29. Ahmad Najib Burhani, "Al-Tawassuth wa al-I'tidâl: The NU and Moderatism in Indonesian Islam," dalam Asian Journal of Social Science, 40, 2012, h. 566567.

30. Tentang definisi ayat-ayat Makkiyyah dan ayat-ayat Madaniyyah dijelaskan di dalam Manna al-Qaththan, Mabâhits fî̀ 'Ulûm al-Qur'ân, Kairo: Maktabah Wahbah, t. th., h. 46-60.

31. Politik identitas mempunyai potensi besar untuk mengacaukan Asia Tenggara, khususnya Indonesia dan potensi tersebut bahkan lebih besar daripada potensi ancaman ekstrimisme radikal. Michael Vatikiotis, "Spreading a Creed of Hate Thy Neighbour," dalam The World Today, Juni \& Juli, 2019, h. 35. 